\title{
Hanne Marlene Dahl ny professor ved Roskilde Universitet
}

kvindelige slægtninge $i$ slutningen af 1920'erne som den første på egnen blev sendt på husholdsningsskole af sin fremsynede mor, rynkede de andre gårdmandskoner næsen - "skal man nu til at gå i skole for at lære husholdning! Det har vi andre jo lært hjemme af vores mødre". Men det var en ny tendens i tiden.

I september 2011 holdt Hanne Marlene Dahl sin tiltrædelsesforelæsning som professor ved Roskilde Universitet, Institut for Samfund og Globalisering. Hermed fik Roskilde Universitet sin første professor inden for forskningsfeltet 'Welfare, Care and Gender'.

Det ville have glædet pioneererne i den danske kvindebevægelse, som kæmpede så længe for at gøre omsorg og husholdning til egentlige fag - i Hanne Marlenes terminologi en professionalisering af det typiske kvindearbejde. Kronen på værket var da der omkring anden verdenskrig blev oprettet videreuddannelser i både sygepleje (1938) 
og husholdning (1945) på Aarhus Universitet.

Som videnskabeligt forskningsfelt i Norden var ikke mindst i starten de norske forskere vigtige. Hvem af os inden for kvindeog kønsforskningens første generation husker ikke det gennemslag, som norske Kari Wærness' begreb 'omsorgsrationalitet' fik en kritik af det ensidige økonomiske rationalitetsbegreb. I 1980 grundlagdes Nordic College of Caring Science i Bergen.

I dag er forskning om 'care' et ekspanderende forskningsfelt internationalt. Hanne Marlene Dahl har været med til at sætte dette forskningsfelt på den akademiske dagsorden i Danmark, bl.a med sin ph.d.afhandling om hjemmehjælpernes udvikling med den iøjnefaldende titel: Fra kitler til eget toj-diskurser om professionalisme, omsorg og køn. Med sine seneste udgivelser, bla. bogen Europeanization, Care and Gender. Global Complexities fra 2011, har hun desuden været med til at gøre den danske og nordiske forskning om omsorg kendt i det internationale forskersamfund.

I sin forskning, som er præget af et Foucault-inspireret, diskurs-analytisk kønsperspektiv, har Hanne Marlene Dahl interesseret sig for bl.a. processerne omkring professionalisering, de-professionalisering, anerkendelse og italesættelse af et område, som hidtil har været 'tavshedsliggjort'. Hun har i sin forskning påpeget, hvordan 'husmoderen' som figur har været vigtig i de skiftende forståelser af hjemmehjælp. Statslig og kommunal styring af feltet og den omvæltning af omsorgsarbejde, som har fundet sted med New Public Management's indtog i omsorgssektoren, er centrale emner i hendes forskning. Den politiske relevans af denne forskningsgren er åbenlys, ikke mindst i disse år, hvor de mange privatiseringer og nye selskabskonstruktioner har rejst en berettiget diskussion om de institu- tionelle rammer for omsorgsarbejdet, og den voksende adskillelse mellem dem, der betaler (det offentlige) og dem, som leverer service-varen og indkasserer pengene. I Sverige er denne diskussion særlig heftig, fordi hedgefonde med deres ensidige motiv om at score hurtige penge nu har gjort deres indtog i omsorgssektoren.

I dag taler alle om 'the global care chain'. Som Hanne Marlene Dahl peger på i sin tiltrædelsesforelæsning er også Danmark og de øvrige nordiske lande i stigende grad blevet involveret i den globale omsorgskæde, selv om vi helst ikke vil se det. I dag er det ikke kun i de sydeuropæiske lande, at legale eller papirløse immigranter passer hus og børn for de kvinder (og deres mænd), som har travlt med karrieren. Også i danske hjem arbejder nu kvinder fra Filippinerne, Thailand eller Den Dominikanske Republik, som regel til en ussel løn. Trods status som 'au pair piger', er der ofte tale om kvinder, som arbejder for at skrabe penge sammen til deres børns forsørgelse og skolegang i hjemlandet.

I sin forskning analyserer Hanne Marlene Dahl omsorgsarbejdets udvikling i et kønsperspektiv. Perspektivet er både kønnets betydning i denne sektor og omstruktureringernes kønsmæssige betydning. Med den nye professors egne ord: "Når jeg arbejder med et kønsperspektiv, så handler det både om hvordan kønnet styres - kønsliggørelse - det som man kan kalde styring af køn. Men det handler derudover også om de kønnede effekter ... af det som tilsyneladende er kønsneutrale temaer, områder og handlinger".

Et stort tillykke til den nye professor.

$$
\begin{array}{r}
\text { Drude Dablerup } \\
\text { Statsvetenskapliga institutionen } \\
\text { Stockholms Universitet }
\end{array}
$$

